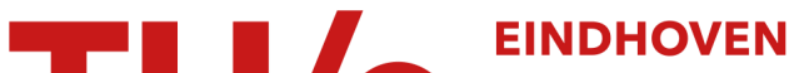 \\ UNIVERSITY OF \\ TECHNOLOGY
}

\section{Surface charge and coagulation of aqueous $\mathrm{ZnO}$ dispersions}

Citation for published version (APA):

Logtenberg, E. H. P., \& Stein, H. N. (1986). Surface charge and coagulation of aqueous $\mathrm{ZnO}$ dispersions. Journal of Colloid and Interface Science, 109(1), 190-200. https://doi.org/10.1016/0021-9797\%2886\%29902948, https://doi.org/10.1016/0021-9797(86)90294-8

DOI:

10.1016/0021-9797\%2886\%2990294-8

10.1016/0021-9797(86)90294-8

Document status and date:

Published: 01/01/1986

\section{Document Version:}

Publisher's PDF, also known as Version of Record (includes final page, issue and volume numbers)

\section{Please check the document version of this publication:}

- A submitted manuscript is the version of the article upon submission and before peer-review. There can be important differences between the submitted version and the official published version of record. People interested in the research are advised to contact the author for the final version of the publication, or visit the $\mathrm{DOI}$ to the publisher's website.

- The final author version and the galley proof are versions of the publication after peer review.

- The final published version features the final layout of the paper including the volume, issue and page numbers.

Link to publication

\section{General rights}

Copyright and moral rights for the publications made accessible in the public portal are retained by the authors and/or other copyright owners and it is a condition of accessing publications that users recognise and abide by the legal requirements associated with these rights.

- Users may download and print one copy of any publication from the public portal for the purpose of private study or research.

- You may not further distribute the material or use it for any profit-making activity or commercial gain

- You may freely distribute the URL identifying the publication in the public portal.

If the publication is distributed under the terms of Article $25 f a$ of the Dutch Copyright Act, indicated by the "Taverne" license above, please follow below link for the End User Agreement:

www.tue.nl/taverne

Take down policy

If you believe that this document breaches copyright please contact us at:

openaccess@tue.nl

providing details and we will investigate your claim. 


\title{
Surface Charge and Coagulation of Aqueous ZnO Dispersions
}

\author{
E. H. P. LOGTENBERG AND H. N. STEIN \\ Laboratory of Colloid Chemistry, Eindhoven University of Technology, P.O. Box 513, \\ $5600 \mathrm{MB}$ Eindhoven, The Netherlands
}

Received October 22, 1984; accepted May 21, 1985

\begin{abstract}
Different pretreatments of $\mathrm{ZnO}$ lead to differences in surface carbonate groups and in interstitial $\mathrm{Zn}$ content, while the $\zeta$ potential is determined only by the concentrations in the electrolyte solution. The rate of coagulation however, is determined by the $\zeta$ potential, independent of the way in which this is arrived at. The surface charge of $\mathrm{ZnO}$ cannot be described by the site-binding model; rather, mutual stimulation of the adsorption of $\mathrm{H}^{+}$and chemisorption of anions is indicated. () 1986 Academic Press, Inc.
\end{abstract}

\section{INTRODUCTION}

$\mathrm{ZnO}$ has been the subject of extended colloid chemical investigations (see, e.g., Refs. (15)). One of the interesting aspects of $\mathrm{ZnO}$ from a colloid chemical point of view is, that one $\zeta$ potential can be found combined with different situations at the $\mathrm{ZnO}$ /aqueous solution phase boundary (different amounts of adsorbed ions, or of interstitial $\mathrm{Zn}$ ). Thus, $\mathrm{ZnO}$ can be used to check whether the interaction between suspended particles is noticeably affected by changes of such parameters.

$\mathrm{ZnO}$ preparations normally have hydroxyl and carbonate groups on their surface (6) but these can be removed by heating. Such surface groups might influence coagulation through changing the adsorption of ions or the dissolution of $\mathrm{Zn}^{2+}$-containing complexes. Thus, Healy and Jellet (1) postulated that coagulation be enhanced by the presence of uncharged polymeric $\mathrm{Zn}(\mathrm{OH})_{2}$ complexes in the solution. However, when removing adsorbed impurities from the $\mathrm{ZnO}$ surface, e.g., by heating, other properties of the solid are effected as well, such as the degree of disorder near the phase boundary; the number of electron donors, etc.

The present investigation aims at elucidating the question whether the coagulation rate of $\mathrm{ZnO}$ is determined once the $\zeta$ potential has been fixed, or whether other properties of the
$\mathrm{ZnO}$ /aqueous electrolyte solution interface influence either attraction or repulsion.

\section{EXPERIMENTAL}

\section{Materials}

Merck "Pro Analysi" samples were used throughout, both for the electrolytes employed $\left(\mathrm{KCl}, \mathrm{KNO}_{3}, \mathrm{KI}\right)$ and for the $\mathrm{ZnO}$ used as starting substance (designated as $\mathrm{ZnO}$ a.r.). Occasionally, $\mathrm{ZnO}$ Highways Ultrapur was employed for comparison.

$\mathrm{ZnO}$ was pretreated by heating in a flow of $\mathrm{O}_{2}$ or $\mathrm{N}_{2}$ at atmospheric pressure for $4 \mathrm{~h}$ at $723 \mathrm{~K}$; these samples are indicated as $\mathrm{ZnO} /$ $\mathrm{O}_{2}$ and $\mathrm{ZnO} / \mathrm{N}_{2}$, respectively, in order to distinguish them from $\mathrm{ZnO}$ "as received" ( $\mathrm{ZnO}$ a.r.).

Treatment of $\mathrm{ZnO}$ with $\mathrm{H}_{2}$ for $4 \mathrm{~h}$ resulted in pronounced sintering, which precluded adsorption and coagulation measurements.

Therefore pretreatment of $\mathrm{ZnO}$ in a reducing atmosphere was performed by heating the sample first for $4 \mathrm{~h}$ in oxygen at $723 \mathrm{~K}$; then $\mathrm{N}_{2}$ was passed through for $15 \mathrm{~min}$; thereafter $\mathrm{H}_{2}$ was passed through and the oven was turned off. The sample was then cooled under a flow of hydrogen. Such samples are indicated as $\mathrm{ZnO} / \mathrm{H}_{2}$.

For further experiments the samples were directly transferred from the ignition tube to 
the apparatus. In some series of experiments, the heating temperature was varied.

Ellipsometry measurements were performed on a $\mathrm{ZnO}$ single crystal, kindly provided by Prof. Heiland (Aachen, GFR) ${ }^{1}$; it had been grown from the vapor phase.

\section{Characterization of the $\mathrm{ZnO}$}

ESR measurements showed, in agreement with Iyengar and Codell (7), a decrease of the signal at $g=1.965$ on heating in $\mathrm{O}_{2}$, while this signal increased on heating in $\mathrm{He}$ and especially so on heating in $\mathrm{H}_{2}$. This signal is attributed to interstitial $\mathrm{Zn}$ (7); its ratio, in the direction $\mathrm{ZnO} / \mathrm{O}_{2}: \mathrm{ZnO}$ a.r.: $\mathrm{ZnO} / \mathrm{He}: \mathrm{ZnO} / \mathrm{H}_{2}$, is about $1: 3: 10: 50$.

The signal at $g=2.003$, ascribed to $\mathrm{O}^{-}$, increases in a similar way to the 1.965 signal by heating in $\mathrm{He}$ or $\mathrm{H}_{2}$, but is not changed significantly by heating in $\mathrm{O}_{2}$.

Interstitial $\mathrm{Zn}$, as determined by Norman's method (8), amounts to $6.3 \mathrm{ppm}$ in $\mathrm{ZnO} / \mathrm{O}_{2}$; $8.5 \mathrm{ppm}$ in $\mathrm{ZnO}$ a.r.; 6.0 ppm in $\mathrm{ZnO} / \mathrm{N}_{2}$; and $74.9 \mathrm{ppm}$ in $\mathrm{ZnO} / \mathrm{H}_{2}$.

The amount of surface hydroxyl groups, determined by Morimoto and Naono's method (9), is $8.3-9.5 \mathrm{OH}$ groups $/ \mathrm{nm}^{2}$ irrespective of pretreatment. The possibility cannot be excluded that the $\mathrm{ZnO}$ is covered by $\mathrm{OH}$ groups during the transfer from the ignition tube to the analytic apparatus; but then the same effect should be expected for the $\mathrm{ZnO}$ used in surface charge, electrokinetic and coagulation experiments.

Surface carbonate groups were determined in the same apparatus as used for $\mathrm{OH}$ group determination, with $1 \mathrm{M} \mathrm{HCl}$ solution replacing the methyl magnesium iodide reagent in the latter. $\mathrm{ZnO}$ a.r. contained 1.95 groups/ $\mathrm{nm}^{2}$; heat-treated $\mathrm{ZnO}: 0 \pm 0.3$ groups $/ \mathrm{nm}^{2}$, irrespective of the atmosphere during heating. The carbonate groups disappeared at 473-493 $\mathrm{K}$, in agreement with Morimoto and Morishige's data (6).

\footnotetext{
${ }^{1}$ The authors express their gratitude to Professor Heiland for placing the crystal at their disposal.
}

The surface area of heat-treated $\mathrm{ZnO}$, measured by nitrogen adsorption, amounted to 3.5 $\mathrm{m}^{2} \mathrm{~g}^{-1}$.

\section{EXPERIMENTAL PROCEDURES}

Electrokinetic and coagulation rate measurements were performed in dilute suspensions ( $3.2 \mathrm{mg}$ in $25 \mathrm{ml}$ ), prepared as described previously (10). Adjustment of the $\mathrm{pH}$ in the initial suspension was much more rapid for preheated $\mathrm{ZnO}$ than for $\mathrm{ZnO}$ a.r.: for the preheated $\mathrm{ZnO}$ only one major $\mathrm{pH}$ correction and one dispersion procedure were necessary for obtaining a stable $\mathrm{pH}$.

The initial coagulation rate was calculated from $E$ (= light extinction) versus $t$ (= time) graphs, through $(d E / d t)_{t \rightarrow 0} / E_{0}^{2} ; E_{0}=E$ at $t$ $=0$. The philosophy for so doing is, that the coagulation rate is proportional to $n^{2}(n=$ the number of particles), while $E_{0}$ is proportional to $n_{0}$. Thus a comparison of the initial coagulation rate for suspensions with slightly varying solid concentrations is achieved. Only relative coagulation rates are presented in the present paper.

Surface charge measurements were performed in concentrated suspensions $(7.00 \mathrm{~g}$ $\mathrm{ZnO}$ in $300 \mathrm{ml}$ ) by the $\mathrm{pH}$ stat method described by Trimbos et al. (5). The liquid phase was, before addition of the $\mathrm{ZnO}$, saturated by $15 \mathrm{mg}$ of $\mathrm{ZnO}$; the attainment of solubility equilibrium was followed through the accompanying $\mathrm{H}^{+}$or $\mathrm{OH}^{-}$consumption. Solubility equilibrium was established in $0.5-15 \mathrm{~h}$, depending on the $\mathrm{pH}$; additional small $\mathrm{ZnO}$ doses did not have any effect. After saturation of the liquid, $7.00 \mathrm{~g}$ of $\mathrm{ZnO}$ was added directly from the ignition tube.

A subsequent net $\mathrm{OH}^{-}$consumption is indicated as $\Gamma_{\mathrm{OH}^{-}-\mathrm{H}^{+}}\left(\mu M \cdot \mathrm{m}^{-2}\right)$; it is negative when a net amount of $\mathrm{H}^{+}$was consumed. All surface charge measurements were performed in the dark.

In some cases, fast titrations were carried out in the same apparatus as used for $\Gamma_{\mathrm{OH}^{-}-\mathrm{H}^{+}}$determination, by the method described in Ref. (5). 
Ellipsometry was performed on a $\mathrm{ZnO}$ single crystal $\left(0.5 \cdot 0.4 \cdot 0.1 \mathrm{~cm}^{3}\right)$ embedded in a resin ("transparent resin No. 3", Struers) by applying a pressure of about $10^{7} \mathrm{~Pa}$ at $403 \mathrm{~K}$. The 0001 crystal face was polished successively with 3-, 1-, and 0.25- $\mu \mathrm{m}$ diamond powder, and rinsed with $76 \%$ ethanol; after drying in hot air, the crystal was stored over $\mathrm{CaCl}_{2}$.

The ellipsometer used was a Rudolph automatic RR 2000 apparatus. Before measurements, the reflectivity of the crystal was checked in air, and then the crystal was immersed in a $0.01 \mathrm{M} \mathrm{KCl}$ solution in a thermostated vessel, under a flow of nitrogen. The $\mathrm{pH}$ was varied between 7 and 11. The ellipsometric angles $\Delta$ and $\psi(11)$ were registered as a function of time.

\section{RESULTS AND DISCUSSION}

\section{Ellipsometry}

No changes of the ellipsometric angles were found for up to 2 days at $\mathrm{pH}=9.00$; neither were changes detected at other $\mathrm{pH}$ values. (Here measurements were restricted to $5 \mathrm{~min}$ per $\mathrm{pH}$ value.)

From this negative result, we conclude that no layer characterized by a separate refractive index and extinction coefficient is formed at the $\mathrm{ZnO} /$ aqueous electrolyte solution interface. Thus, no $\mathrm{Zn}(\mathrm{OH})_{2}$ formation other than covering of the $\mathrm{ZnO}$ surface by $\mathrm{OH}$ groups occurs. The negative result of the ellipsometry measurements is a strong argument against the formation of a porous gel layer on the $\mathrm{ZnO}$ surface $(12,13)$, although a "layer" of subnanometer thickness cannot rigorously be excluded.

\section{Measurements of $\mathrm{\Gamma}_{\mathrm{OH}^{-}-\mathrm{H}^{+}}$}

The $\Gamma_{\mathrm{OH}^{-}-\mathrm{H}^{+}}$measurements for $\mathrm{ZnO}$ a.r. show the same characteristics as reported by Trimbos et al. (5), which had been found by other investigators as well $(2,3)$. Thus, a fast $\mathrm{H}^{+}$or $\mathrm{OH}^{-}$consumption was followed by a slow process.

This slow process could be suppressed by preheating. Figure 1 shows typical results ob-

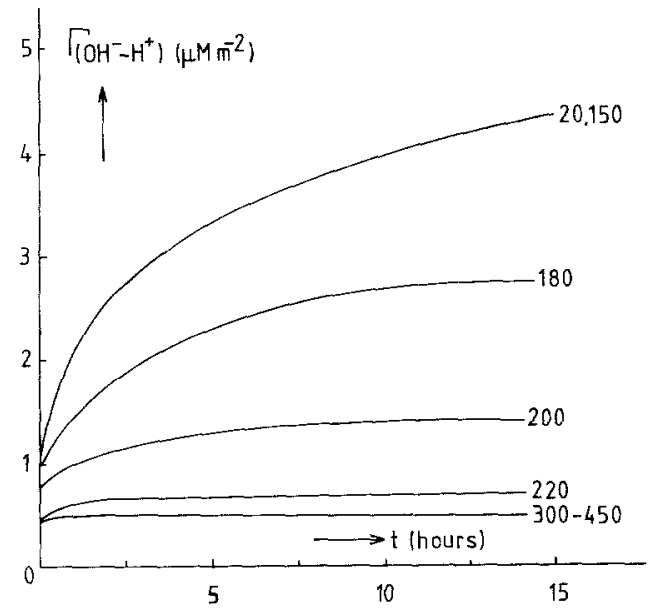

FIG. 1. Net consumption of $\mathrm{H}^{+}$or $\mathrm{OH}^{-}$in $10^{-2} \mathrm{M} \mathrm{KCl}$ at $\mathrm{pH}=10.00$ as a function of time for samples or $\mathrm{ZnO}$, ignited in an atmosphere of oxygen at different temperatures (parameter of the curves) for $4 \mathrm{~h}$.

tained for $\mathrm{ZnO}$ samples pretreated in oxygen at various temperatures, at $\mathrm{pH}=10.00$. Especially remarkable is that the slow process disappears at the same preheating temperature $(473-493 \mathrm{~K})$ where, in agreement with Morimoto and Morishige (6), expulsion of the chemisorbed $\mathrm{CO}_{2}$ from the $\mathrm{ZnO}$ surface was found. The suppression of the slow process was found for $\mathrm{ZnO}$ Highways Ultrapur at the same temperature, and the same phenomena were observed for $\mathrm{ZnO} / \mathrm{O}_{2}, \mathrm{ZnO} / \mathrm{N}_{2}$, and $\mathrm{ZnO} / \mathrm{H}_{2}$.

Heat treatments in oxidizing and in reducing atmospheres, though effecting pronounced changes in the interstitial $\mathrm{Zn}$ content, did not lead to differences in $\Gamma_{\mathrm{OH}^{-}-\mathrm{H}^{+}}$(see Figs. 2 and 3 ), at least not in the present experiments performed in the dark.

Thus, we must conclude that this slow process is connected with surface carbonate groups rather than with a surface reaction involving $\mathrm{ZnOH}$ groups with mobile charge carriers, as suggested earlier by the kinetics of the process (5). Similarly slow $\mathrm{H}^{+}$or $\mathrm{OH}^{-}$consumption as found for $\mathrm{ZnO}$ a.r. was found using solid $\mathrm{NaHCO}_{3}$ or a basic zinc carbonate.

Experiments in $10^{-3} \mathrm{M} \mathrm{KCl}$ solutions show 


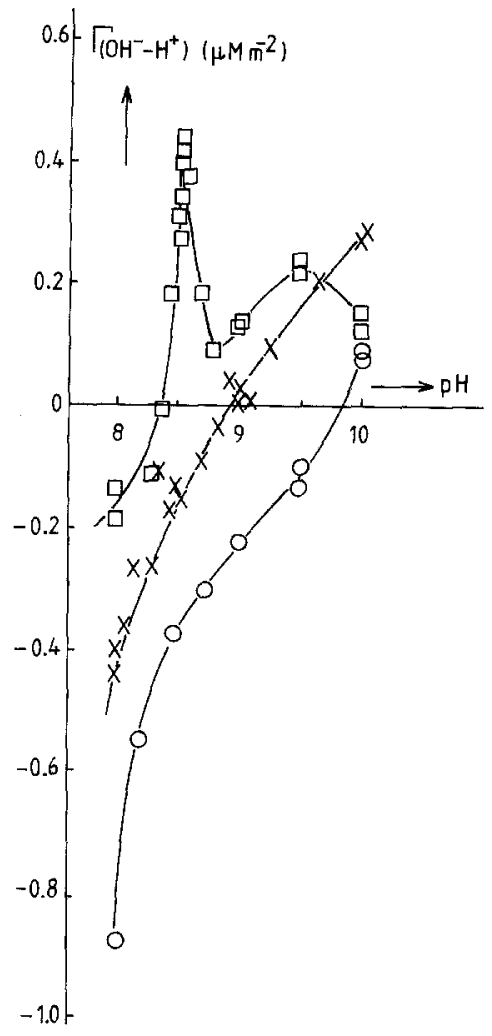

Fig. 2. Net consumption of $\mathrm{H}^{+}$or $\mathrm{OH}^{-}$, on addition of $7.00 \mathrm{~g} \mathrm{ZnO} / \mathrm{O}_{2}$ to $300 \mathrm{ml} \mathrm{KCl}$ solution, as a function of pH: $\square 10^{-3} M ; \times 10^{-2} M ; O 10^{-1} M$.

a pronounced peak in the adsorption curve at $\mathrm{pH}=8.55$. Similar though slightly different phenomena were observed in $10^{-3} \mathrm{M} \mathrm{KNO}_{3}$ solutions (Fig. 4). Such peaks were not found on fast titrations: $\Gamma_{\mathrm{OH}^{-}-\mathrm{H}^{+}}$as measured by fast titrations follows the course expected in the absence of a peak.

This is illustrated in Fig. 5. Here data obtained by the $\mathrm{pH}$ stat method are compared with data obtained on fast titrations: On adding $\mathrm{ZnO}$ to the electrolyte solution (which had been previously saturated towards $\mathrm{ZnO}$ ), first the $\mathrm{pH}$ stat value for $\mathrm{\Gamma}_{\mathrm{OH}^{-}-\mathrm{H}^{+}}$was recorded. Afterwards fast titrations were carried out in the same suspensions, as follows:

(a) The titration was started at an initial $\mathrm{pH}=9.00$ to $\mathrm{pH}=8.30$ and back (lower dotted curve in Fig. 5);

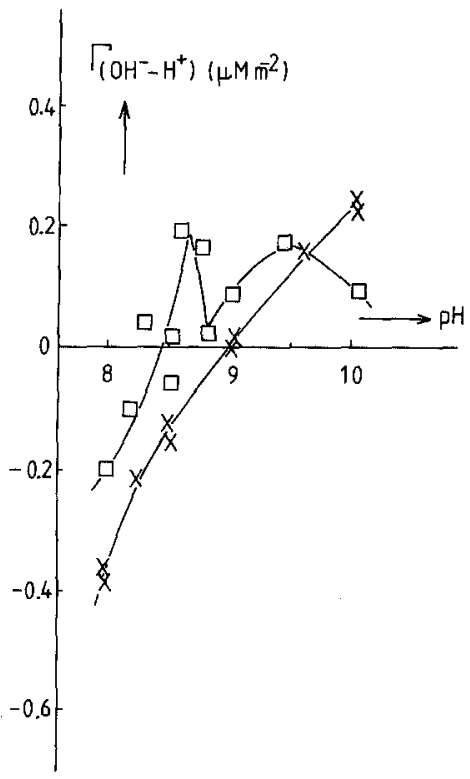

FIG. 3. As Fig. 2, for $\mathrm{ZnO} / \mathrm{H}_{2}$.

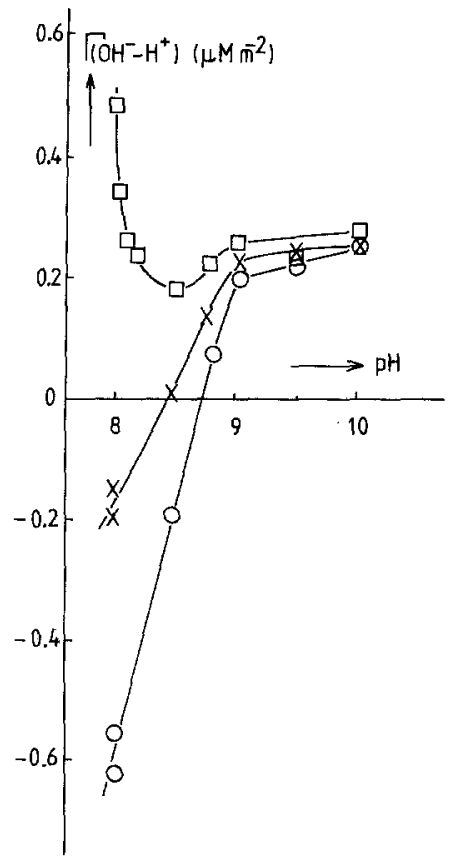

FIG. 4. Net consumption of $\mathrm{H}^{+}$or $\mathrm{OH}^{-}$, on addition of $7.00 \mathrm{~g} \mathrm{ZnO} / \mathrm{O}_{2}$ to $300 \mathrm{ml} \mathrm{KNO} \mathrm{KN}_{3}$ solution, as a function of $\mathrm{pH} ; \square 10^{-3} \mathrm{M} ; \times 10^{-2} \mathrm{M} ; \bigcirc 10^{-1} \mathrm{M}$. 
(b) The titration was started at an initial $\mathrm{pH}=8.55$, to $\mathrm{pH}=9.00$, then back to $\mathrm{pH}$ $=8.30$ and afterwards up to $\mathrm{pH}=8.55$ again (upper dotted curve in Fig. 5).

The dotted curves correspond in all cases to the sum of the $\Gamma_{\mathrm{OH}^{-}-\mathrm{H}^{+}}$values obtained during $\mathrm{ZnO}$ addition, and during the fast titration. Similar phenomena were observed in $10^{-3} M \mathrm{KNO}_{3}$ solutions.

If the $7.00 \mathrm{~g} \mathrm{ZnO}$ in a $\mathrm{pH}$ stat experiment was added in two successive portions of 3.50 g each, with an interval of either $10 \mathrm{~min}$ or 24 $\mathrm{h}$, only the first portion showed the peak value of $\Gamma_{\mathrm{OH}^{-}-\mathrm{H}^{+}}$; while at other $\mathrm{pH}$ values for both portions the same $\Gamma_{\mathrm{OH}^{-}-\mathrm{H}^{+}}$(in $\mu M / \mathrm{m}^{2}$ ) was found on addition of $7.00 \mathrm{~g} \mathrm{ZnO}$.

Thus, for interpreting the $\mathrm{\Gamma}_{\mathrm{OH}^{--}-\mathrm{H}^{+}}$peaks, we have the following data:

(1) The peaks are related to the first addition of a substantial amount of $\mathrm{ZnO}$; they are observed neither on addition of the $15 \mathrm{mg}$ of $\mathrm{ZnO}$ necessary for previous saturation of the solution, nor an addition of a second portion, nor during titration of the suspension after $\mathrm{ZnO}$ addition;

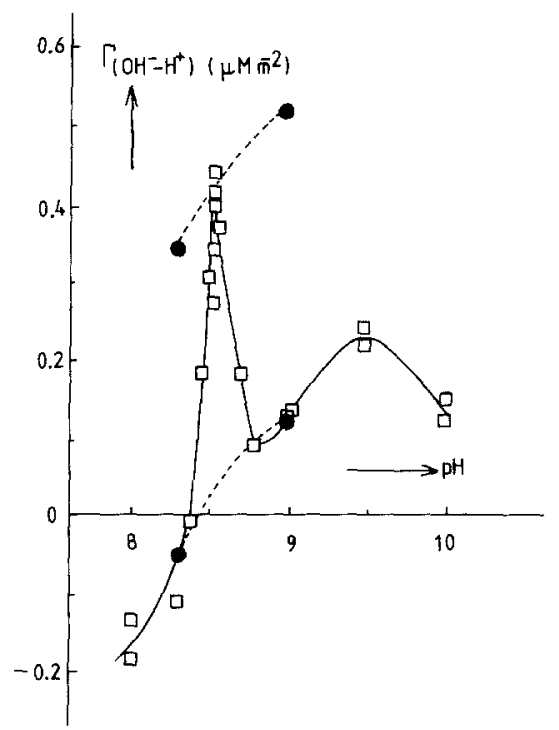

FIG. 5. Comparison of pH stat data $(\square-\square)$ with fast titration (--) for $\mathrm{ZnO} / \mathrm{O}_{2}$ in $10^{-3} \mathrm{M} \mathrm{KCl}$.
(2) The peaks are influenced by the type of anion present (compare Figs. 2 and 4), but the peaks disappear at higher electrolyte concentration;

(3) The peaks are found both for $\mathrm{ZnO} / \mathrm{O}_{2}$ and for $\mathrm{ZnO} / \mathrm{H}_{2}$ (compare Figs. 2 and 3).

The first effect marks the peaks as being due to impurities rather than to properties of the $\mathrm{ZnO}$ itself. But the restriction to the first substantial amount of $\mathrm{ZnO}$ added excludes as causes: traces of $\mathrm{CO}_{2}$ left on the $\mathrm{ZnO}$ during the pretreatment; impurities desorbing from the glass vessel; ion exchange of an anionic impurity on the $\mathrm{ZnO}$ surface with $\mathrm{OH}^{-}$from the electrolyte solution, and adsorption of $\mathrm{OH}^{-}$on cationic impurities on the $\mathrm{ZnO}$ surface. The third effect excludes impurities from the gases used for pretreatment, and interstitial $\mathrm{Zn}$ as causes for the peak adsorption; the disappearance at higher electrolyte concentrations excludes impurities from the supporting electrolyte.

An explanation for the phenomena of the peaks is that the $\mathrm{ZnO}$ employed contains cationic impurities forming complexes both with $\mathrm{OH}^{-}$and with anions from the supporting electrolyte in a restricted $\mathrm{pH}$ range, leading to saturation after addition of the first substantial amount of $\mathrm{ZnO}$. The differences between $\Gamma_{\mathrm{OH}^{--}-\mathrm{H}^{+}}$observed during $\mathrm{pH}$ stat experiments and during fast titrations indicate that complexes once formed do not react any more with $\mathrm{H}^{+}$or $\mathrm{OH}^{-}$.

We have dealt rather extensively with these peaks, although they are related to impurities, because similar phenomena might complicate adsorption data obtained by the $\mathrm{pH}$ stat method for other oxides as well; such data should always be supplemented by fast titrations.

\section{The Effect of Anions on $\mathrm{\Gamma}_{\mathrm{OH}^{-}-\mathrm{H}^{+}}$}

Figures 6 and 7 show the dependence of $\Gamma_{\mathrm{OH}^{-} \mathrm{H}^{+}}$on increasing electrolyte concentration. Quite generally, $\Gamma_{\mathrm{OH}^{-}-\mathrm{H}^{+}}$shifts toward more positive values with increasing electro- 


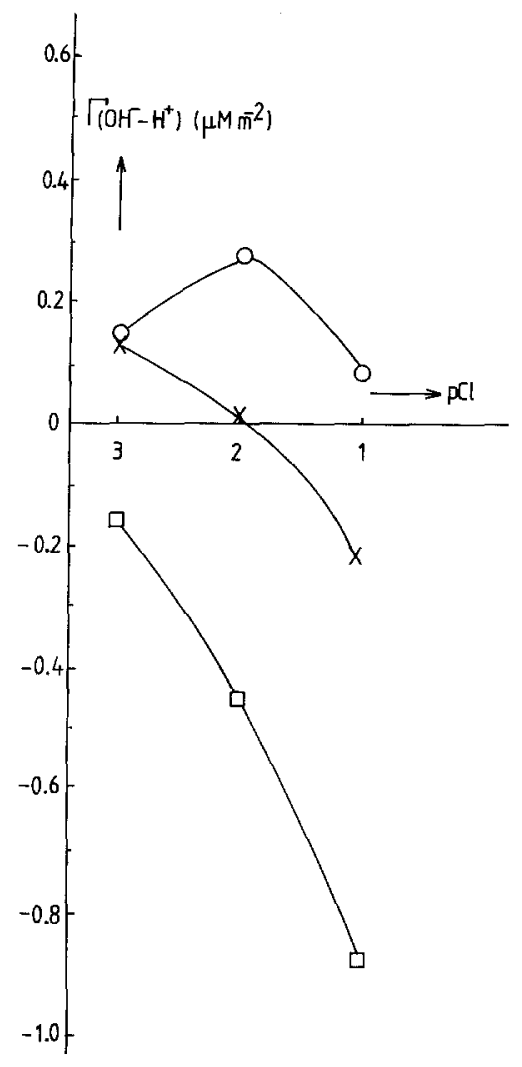

FiG. 6. Net consumption of $\mathrm{H}^{+}$or $\mathrm{OH}^{-}$for additions of $7.00 \mathrm{~g} \mathrm{ZnO} / \mathrm{O}_{2}$ to $300 \mathrm{ml} \mathrm{KCl}$ solutions as a function of pCl: $\bigcirc \mathrm{pH}=10 ; \times \mathrm{pH}=9 ; \square \mathrm{pH}=8$.

lyte concentration, but does so differently for $\mathrm{KCl}$ and for $\mathrm{KNO}_{3}$. The value in Fig. 7 for $\mathrm{pH}=8$ in $10^{-3} \mathrm{MKNO}_{3}$ solution is connected with a "peak," and thus influenced by impurities in the $\mathrm{ZnO}$.

The data are consistent with the hypothesis that anions from the supporting electrolyte are chemisorbed by the $\mathrm{ZnO}$ and stimulate the adsorption of $\mathrm{H}^{+}$(and/or hinder the adsorption of $\mathrm{OH}^{-}$).

\section{Electrokinetic Measurements}

Figure 8 shows the $\zeta$ potential vs the $\mathrm{pH}$ for $\mathrm{ZnO} / \mathrm{O}_{2}$ in $10^{-2} \mathrm{M} \mathrm{KCl}$ solutions. Five series of measurements are shown; each series comprizes a number of $\zeta$ potential measurements at different $\mathrm{pH}$ values, performed on one sam-

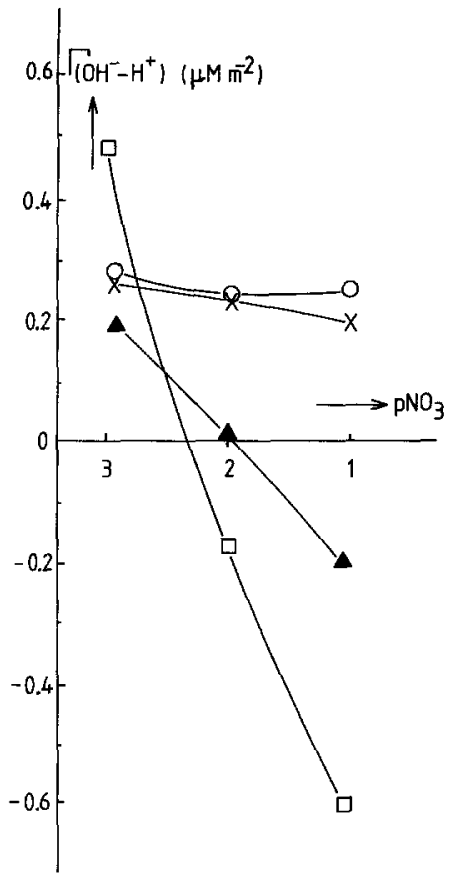

FIG. 7. As Fig. 6 in $\mathrm{KNO}_{3}$ solutions: $\triangle \mathrm{pH}=8.5$.

ple of $\mathrm{ZnO} / \mathrm{O}_{2}$. Comparison with data for $\mathrm{ZnO}$ a.r. (10) shows that heating in oxygen results in pronounced (and not quite reproducible)

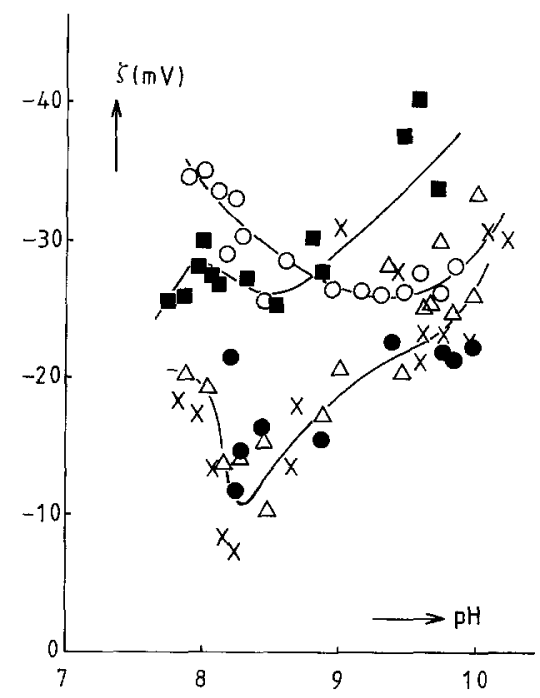

FIG. 8. $\zeta$ potential as a function of $\mathrm{pH}$ for $\mathrm{ZnO} / \mathrm{O}_{2}$ in $10^{-2} \mathrm{M} \mathrm{KCl}$. Results of five series. 
shifts of the $\zeta(\mathrm{pH})$ curve. Notwithstanding the differences between curves obtained on different $\mathrm{ZnO} / \mathrm{O}_{2}$ samples, the curves show similar characteristics: $\zeta$ remains negative for 7.8 $<\mathrm{pH}<10$, and the absolute value of the $\zeta$ potential shows a minimum (though this is rather shallow for two samples). The reproducibility of the $\zeta$ potential measurements for $\mathrm{ZnO}$ a.r., $\mathrm{ZnO} / \mathrm{H}_{2}$, and $\mathrm{ZnO} / \mathrm{N}_{2}$ was far more satisfactory. The characteristic turn of the $\zeta$ potential to more negative values with decreasing $\mathrm{pH}$ will be called an "inversion" of the $\zeta(\mathrm{pH})$ curve.

The same type of curve is found for $\mathrm{ZnO} /$ $\mathrm{H}_{2}$ in $10^{-2} \mathrm{M} \mathrm{KCl}$ solutions (Fig. 9), but in $\mathrm{KNO}_{3}$ or $\mathrm{KI}$ solutions different phenomena are observed (see Figs. 10 and 11, respectively). The final turning (at relatively low $\mathrm{pH}$ values) towards positive $\zeta$ potential values, found for $\mathrm{KNO}_{3}$, is to be expected in $\mathrm{KCl}$ and $\mathrm{KI}$ solutions as well, although at lower $\mathrm{pH}$ values than comprised in the present investigation. With $\mathrm{KNO}_{3}$ solutions, the inversion of the $\zeta$ $(\mathrm{pH})$ curve is restricted to a rather narrow $\mathrm{pH}$ range and thus might easily escape detection on scanning the $\mathrm{pH}$ range.

Such an inversion in the $\zeta(\mathrm{pH})$ curve has

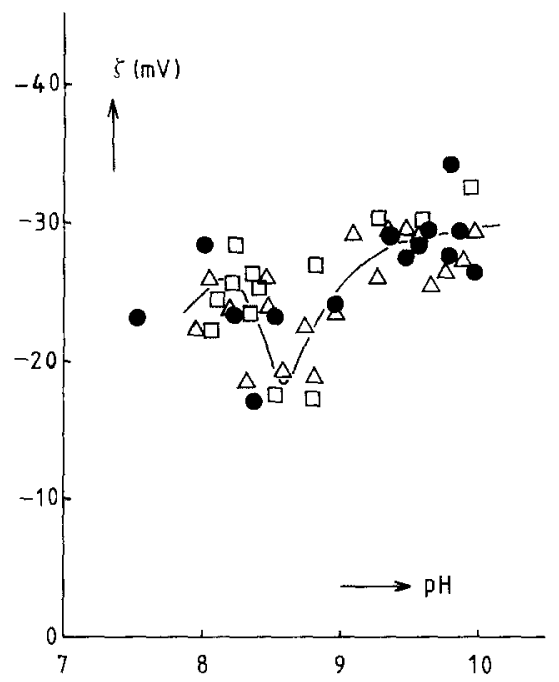

FIG. 9. $\zeta$ potential as a function of $\mathrm{pH}$ for $\mathrm{ZnO} / \mathrm{H}_{2}$ in $10^{-2} \mathrm{MKCl}$. Results of three series.

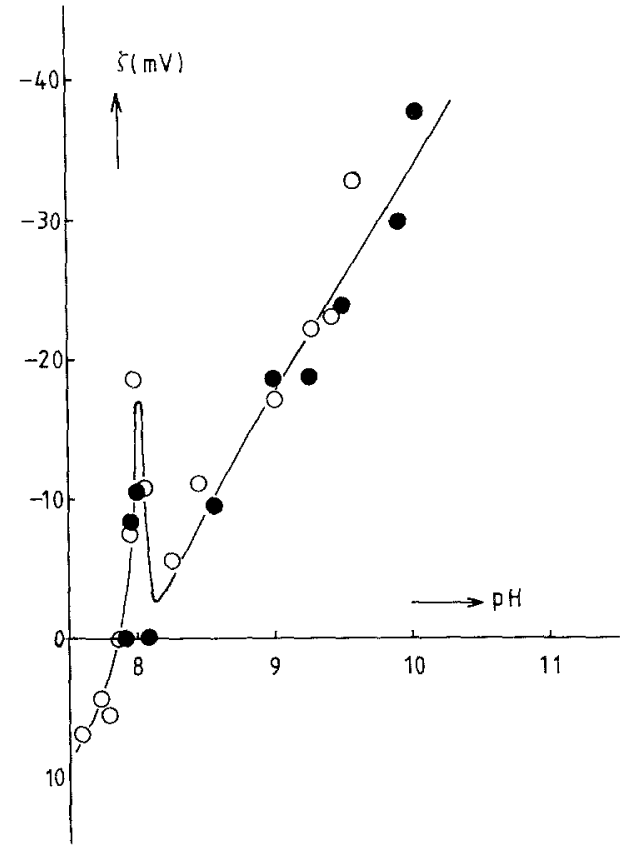

FiG. 10. $\zeta$ potential as a function of $\mathrm{pH}$ for $\mathrm{ZnO} / \mathrm{O}_{2}$ in $10^{-2} \mathrm{MKNO}_{3}$. Results of two series.

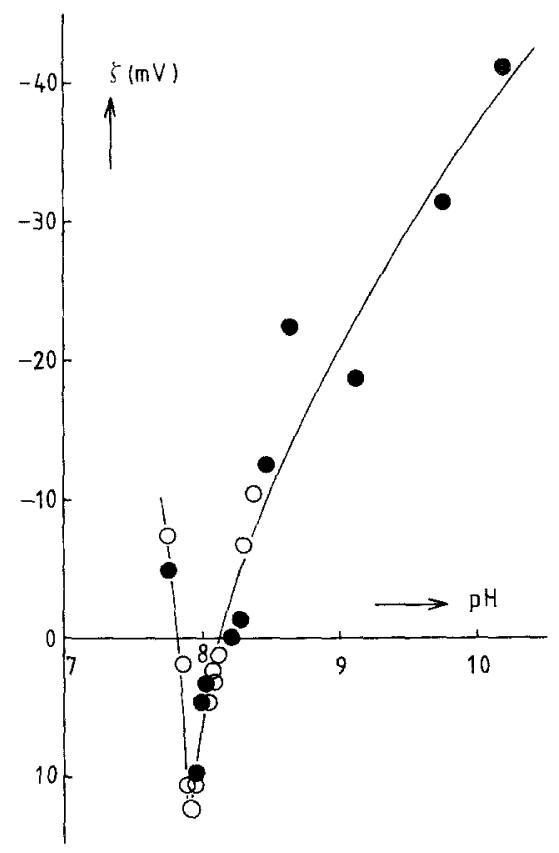

FIG. 11. $\zeta$ potential as a function of $\mathrm{pH}$ for $\mathrm{ZnO} / \mathrm{O}_{2}$ in $10^{-2} M \mathrm{KI}$. Results of two series. 
been reported previously by Healy and Jellet (1) and by Trimbos and Stein (5) though not by Nechaev and Shein (14) nor by Ray c.s. (15). The reason for this discrepancy is not clear, too little data being provided by the latter two groups on the $\mathrm{ZnO}$ samples.

The $\zeta(\mathrm{pH})$ inversion can be understood as follows: At high $\mathrm{pH}$ values, $\zeta$ is strongly negative; the charge behind the electrokinetic slipping plane here consists predominantly of dissociated surface hydroxyl groups ( $\mathrm{ZnO}^{-}$) which are only partially compensated by adsorbed cations. With decreasing $\mathrm{pH}$, this charge decreases; but simultaneously anions from the supporting electrolyte are chemisorbed to an increasing extent because they experience less repulsion. This in turn leads to an increased adsorption of $\mathrm{H}^{+}$ions, as evidenced by the effect of increasing electrolyte content on $\Gamma_{\mathrm{OH}^{-}-\mathrm{H}^{+}}$(Figs. 6 and 7).

In a certain $\mathrm{pH}$ range the increasing anion chemisorption appears to predominate the effect of increasing $\mathrm{H}^{+}$adsorption (or decreasing $\mathrm{ZnOH}$ dissociation) on the $\zeta$ potential: in this

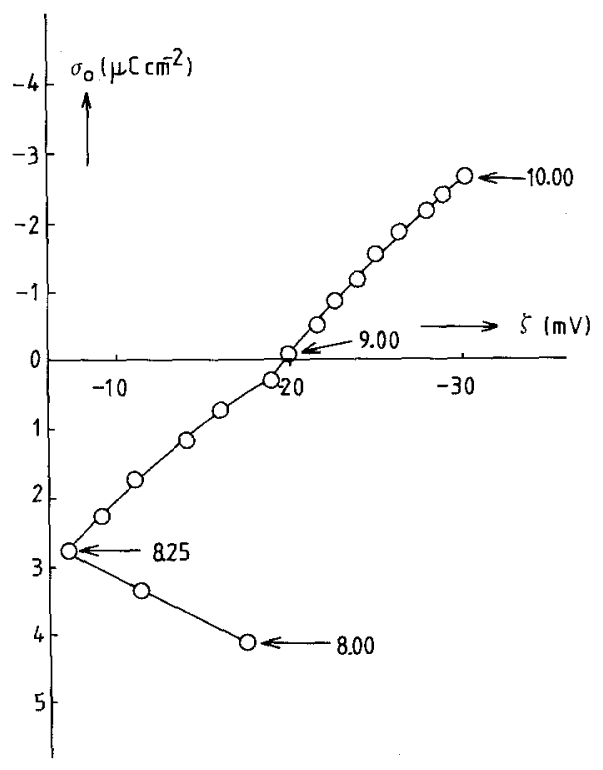

FIG. 12. Surface charge as a function of $\zeta$ potential $(\mathrm{ZnO} /$ $\mathrm{O}_{2}$ in $10^{-2} M \mathrm{KCl}$ ). The figures near the arrows indicate $\mathrm{pH}$ values.

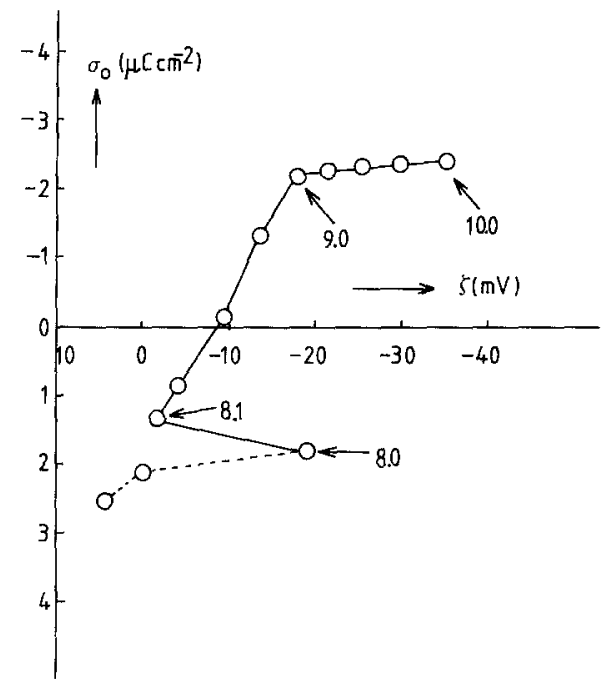

FIG. 13. As Fig. 12, in $10^{-2} M \mathrm{KNO}_{3}$.

$\mathrm{pH}$ range the $\zeta(\mathrm{pH})$ inversion occurs. However, when the energetically most favorable sites for anion chemisorption become more and more occupied, the predominance of increasing anion chemisorption over increasing $\mathrm{H}^{+}$adsorption with decreasing $\mathrm{pH}$ ceases. Then the net charge behind the electrokinetic slipping plane $\left(\sigma_{\zeta}\right)$ turns toward more positive values.

In the range of compositions and $\mathrm{pH}$ values scanned in the present investigation, the turning point towards more positive $\sigma_{\zeta}$ values has been reached only for $\mathrm{KNO}_{3}$ solutions.

In the Figs. 12 and 13, we have illustrated this mechanism by plotting the surface charge $\sigma_{0}$ against $\zeta$. Figure 12 relates to one set of data for $\mathrm{ZnO} / \mathrm{O}_{2}$ in $10^{-2} \mathrm{M} \mathrm{KCl}$ (cf. Fig. 8); the other sets showed the same behavior.

It is seen that, when $\sigma_{0}$ becomes more positive than a certain value $\left(2.8 \mu \mathrm{C} \cdot \mathrm{cm}^{-2}\right.$ in $\mathrm{KCl}$ solutions, $1.4 \mu \mathrm{C} \cdot \mathrm{cm}^{-2}$ in $\mathrm{KNO}_{3}$ solutions), the $\zeta$ potential and consequently the net charge behind the electrokinetic slipping plane become more negative with increasing positive $\sigma_{0}$ values.

This fact is not compatible with the site binding model $(16,17)$, where $\mathrm{Cl}^{-}$or $\mathrm{NO}_{3}^{-}$ions can be adsorbed only on $\mathrm{ZnOH}_{2}^{+}$sites leading 
to $\mathrm{ZnOH}_{2}^{+} \mathrm{Cl}^{-}$and $\mathrm{ZnOH}_{2}^{+} \mathrm{NO}_{3}^{-}$groups, respectively. Our results are compatible with the view that, while $\mathrm{H}^{+}$adsorption is simulated by chemisorbed anions (cf. Figs. 6 and 7), the chemisorption of anions in turn is stimulated by $\mathrm{H}^{+}$adsorption, being determined by the local rather than by the average potential $(5,18)$.

The possibility cannot be excluded that the $\zeta(\mathrm{pH})$ inversion is connected with impurities in the $\mathrm{ZnO}$; it occurs in the $\mathrm{pH}$ range where peaks due to impurities are found in the $\Gamma_{\mathrm{OH}^{-}-\mathrm{H}^{+}}$vs. pH curves, though at lower electrolyte concentrations. Nevertheless, it is remarkable that the negative charges behind the electrokinetic slipping plane in this $\mathrm{pH}$ region are not compensated either by additional $\mathrm{H}^{+}$ adsorption or by desorption of anions.

\section{Coagulation Rate}

In view of the uncertainties in the collision frequencies (10) we will restrain here from a comparison between the coagulation rates observed and those expected from theory; in the context of the present paper especially comparisons between the coagulation rates shown

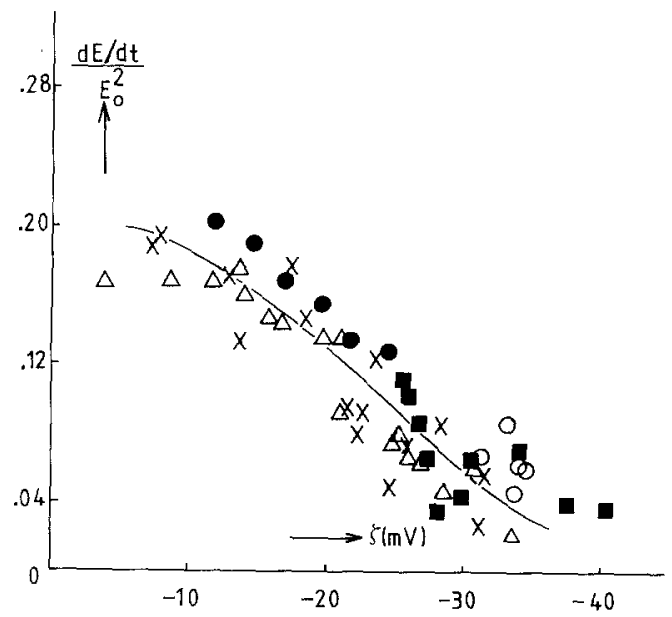

FIG. 14. Coagulation rate as a function of $\zeta$ potential ( $\mathrm{ZnO} / \mathrm{O}_{2}$ in $10^{-2} \mathrm{M} \mathrm{KCl}$ ). Results of five series (compare Fig. 9).

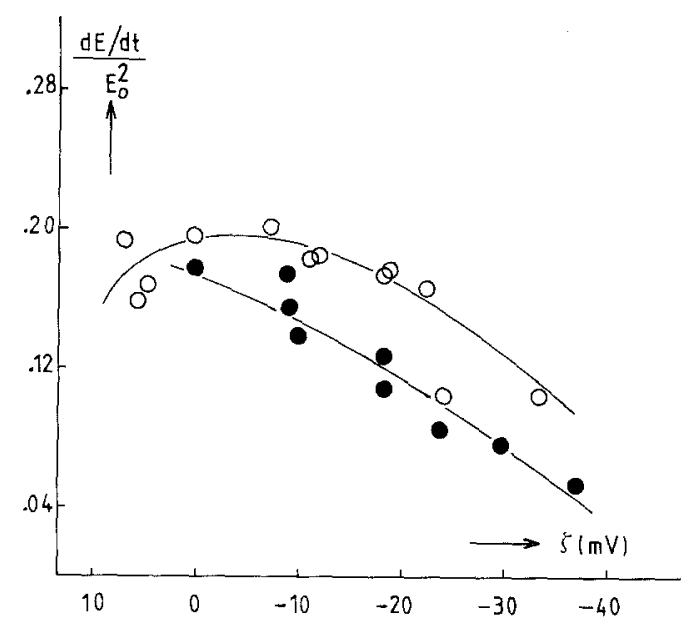

FiG. 15. Coagulation rate as a function of $\zeta$ potential ( $\mathrm{ZnO} / \mathrm{O}_{2}$ in $10^{-2} M \mathrm{KNO}_{3}$ ). Results of two series.

by $\mathrm{ZnO} / \mathrm{O}_{2}$ and $\mathrm{ZnO} / \mathrm{H}_{2}$ in different environments are of interest.

Figures 14-16 present data for the coagulation rate of $\mathrm{ZnO} / \mathrm{O}_{2}$ at $10^{-2} M \mathrm{KCl}, \mathrm{KNO}_{3}$, and $\mathrm{KI}$ solutions, respectively. In spite of differences in $\zeta(\mathrm{pH})$ curves for various samples of $\mathrm{ZnO} / \mathrm{O}_{2}$, of the fact that one $\zeta$ potential value can be accompanied by quite different values of $\Gamma_{\mathrm{OH}^{-}-\mathrm{H}^{+}}$, and of differences in $\zeta(\mathrm{pH})$

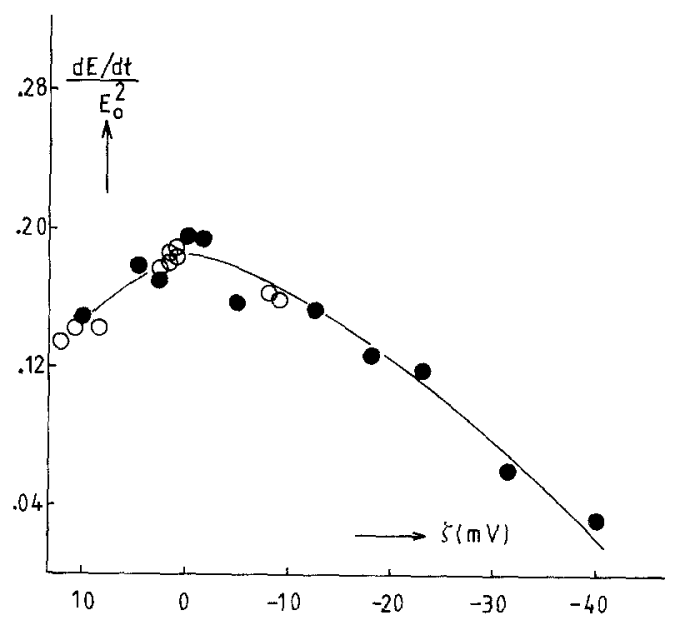

FIG. 16. Coagulation rate as a function of $\zeta$ potential $\left(\mathrm{ZnO} / \mathrm{O}_{2}\right.$ in $\left.10^{-2} M \mathrm{KI}\right)$. Results of two series. 
between different electrolytes, the coagulation rate is determined by the $\zeta$ potential value only.

Neither does variation in the atmosphere during heating result in pronounced changes in coagulation rate (Fig. 17). Even the question whether $\mathrm{ZnO}$ is preheated or not does not appear in distinct differences in coagulation rate.

Thus, the interaction between $\mathrm{ZnO}$ particles can be described by the same attraction irrespective of the amount of interstitial $\mathrm{Zn}$ and the presence of carbonate groups on the surface, while the repulsion is determined once the $\zeta$ potential has been fixed.

\section{CONCLUSION}

The present study leads to the conclusion, that both chemisorption and Hamaker constant are insensitive toward changes in pretreatment conditions and thus to differences in interstitial $\mathrm{Zn}$ concentrations.

The insensitivity of chemisorption towards changes in interstitial $\mathrm{Zn}$ concentrations is evidenced by the absence of a difference in PZC shift between $\mathrm{ZnO} / \mathrm{O}_{2}$ and $\mathrm{ZnO} / \mathrm{H}_{2}$ on going from $10^{-2} M \mathrm{KCl}$ to $10^{-3} M \mathrm{KCl}$ (see Figs. 2

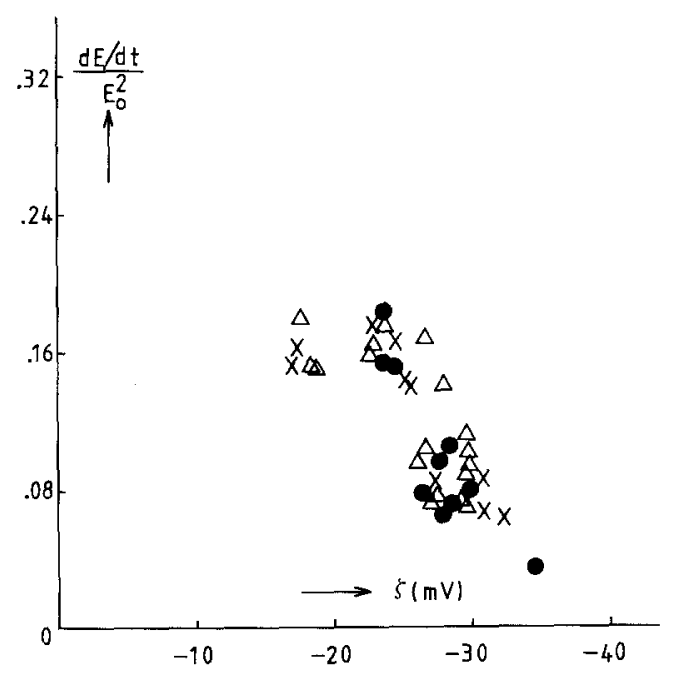

FiG. 17. Coagulation rate as a function of $\zeta$ potential $\left(\mathrm{ZnO} / \mathrm{H}_{2}\right.$ in $\left.10^{-2} \mathrm{M} \mathrm{KCl}\right)$. Results of three series. and 3); the insensitivity of the Hamaker constant is shown by the absence of a difference in coagulation rate between $\mathrm{ZnO} / \mathrm{O}_{2}$ and $\mathrm{ZnO} /$ $\mathrm{H}_{2}$, once the $\zeta$ potential has been fixed (see the Figs. 14-17).

This conclusion may come as a surprise. Changes in interstitial $\mathrm{Zn}$ in $\mathrm{ZnO}$ are expected to lead to changes in surface conductivity in the solid, because interstitial $\mathrm{Zn}$ can act as a donor in $\mathrm{ZnO}$. Chemisorption of ions could be expected to depend on surface conductivity because the latter influences the potential changes induced by an ion in its vicinity. The Hamaker constant, on the other hand, is related to the polarizability of the material forming the disperse phase, and an interstitial $\mathrm{Zn}$ atom will have a considerably larger polarizability than $\mathrm{Zn}^{2+}$ or $\mathrm{O}^{2-}$ at lattice sites. Nevertheless, the results of the present study do not leave any doubt with regard to the conclusion mentioned.

An explanation of this result is that the interstitial $\mathrm{Zn}$ concentrations reached by the reducing conditions during pretreatment remain too low to influence chemisorption and Hamaker constant.

\section{SUMMARY}

Adsorption measurements, coagulation data, and measurements of $\zeta$ potential in the $\mathrm{ZnO}$-aqueous electrolyte system have been presented. The mechanism of adsorption and the rate of coagulation are not significantly influenced by the changes in solid-state properties of $\mathrm{ZnO}$. The rate of coagulation of $\mathrm{ZnO}$ is fully determined by the $\zeta$ potential value.

\section{ACKNOWLEDGMENT}

The authors express their gratitude to Mrs. Dr. W. Visscher for assistance with the ellipsometry measurements.

\section{REFERENCES}

1. Healy, T. W., and Jellet, V. R., J. Colloid Interface Sci. 24, 41 (1967).

2. Blok, L., Ph.D. thesis, Utrecht, 1968. 
3. Blok, L., and de Bruyn, Ph. L., J. Colloid Interface Sci. 32, 518 (1970).

4. Lohmann, F., Ber. Bunsenges. 70, 428 (1966).

5. Trimbos, H. F. A., and Stein, H. N., Stein, J. Colloid Interface Sci. 77, 386 (1980).

6. Morimoto, T., and Morishige, K., J. Phys. Chem. 79, 1573 (1975).

7. Iyengar, R. D., and Codell, M., Adv. Colloid Interface Sci. 3, 365 (1972).

8. Norman, V. J., Analyst 89, 261 (1964).

9. Morimoto, T., and Naono, H., Bull. Chem. Soc. Japan 46, 2000 (1973).

10. Logtenberg, E. H. P., and Stein, H. N., J. Colloid Interface Sci. 104, 258 (1985).
11. Visscher, W., Z. Werkstofftech. 4, 302 (1973).

12. Lyklema, J., J. Electroanal. Chem. 18, 341 (1968).

13. Perram, J. W., Hunter, R. J., and Wright, H. J. L., Aust. J. Chem. 27, 461 (1974).

14. Nechaev, E. A., and Shein, V. N., Kolloidn. Zh. 41, 301 (1979).

15. Ray, K. C., Roy, S. K., and Khan, S., Indian J. Chem. Sect. A, 16, 675 (1978).

16. Yates, D. E., Levine, S., and Healy, T. W., J. Chem. Soc. Faraday Trans. I 70, 1807 (1974).

17. Davies, J. A., James, R. O., and Leckie, J. O., J. Colloid Interface Sci. 63, 480 (1978).

18. van Diemen, A. J. G., and Stein, H. N., J. Colloid Interface Sci. 67, 213 (1978). 